\title{
Inclusivity: An Effective Tool for Achieving Quality Mathematics Classroom Instruction in Nigerian Secondary Schools
}

\author{
Iliya Joseph Bature ${ }^{1, *}$, Bill Atweh ${ }^{2}$, David Treagust ${ }^{2}$ \\ ${ }^{1}$ School of Education, Faculty of Education and Arts, Australian Catholic University, Australia \\ ${ }^{2}$ Science and Mathematics Education Centre, School of Education, Curtin University, Australia
}

Copyright (C) 2016 by authors, all rights reserved. Authors agree that this article remains permanently open access under the terms of the Creative Commons Attribution License 4.0 International License

\begin{abstract}
Mathematics classrooms instruction in Nigeria secondary schools has been termed a major problem to both teachers and their students. Most classroom activities are teacher-centred with students as mere listeners and recipients of knowledge rather than being active initiators of their knowledge. This paper seeks to investigate the effects of introducing inclusion to Nigerian mathematics classroom in combating these problems. Four mathematics teachers taught senior secondary mathematics in three secondary schools in Northern Nigeria for fifteen weeks, adopting the concept of inclusion in their classroom teaching. Using the qualitative case study approach, the researcher used students' interviews and focus group discussions to determine the perceptions, strategies and benefits of using inclusive strategy to mathematics classroom instruction to collect data for this paper. Data collected from focus group interviews were analyzed using grounded theory approach. The results of the study revealed positive changes in students' attitude towards mathematics classroom instructions. This also helped to facilitate students' engagement, collaboration and interest in mathematics during the research as the students felt included in the mathematics classroom instruction. The researchers therefore suggested that adoption of an inclusive mathematics classroom in Nigeria will enable student learning and reduced the teachers domineering attitude during mathematics classroom instruction.
\end{abstract}

Keywords Inclusion, Quality Classroom Instruction, Instructional Strategies

\section{Introduction}

Adopting quality classroom teaching strategies for effective instruction had generated serious debate and ideological controversy among classroom teachers, teacher educators and researchers in mathematics education.
Prominent among the controversies on the development of quality classroom instructional strategies is the call for a shift from the traditional mathematics classroom instruction to more student-centred constructivist approaches [13, 38, 46 \& 47]. This suggests that understanding the strategies to be adopted in sharing knowledge with future generations of teachers, engineers and other mathematical related fields is a necessary ingredient to achieving quality mathematics classroom instruction [26]. For example, John Dewey was of the view that one of the saddest things about mathematics classroom instruction is the lack of wisdom of most of our experience and successful mathematics teachers to transfer their knowledge and experiences to the inexperience and preservice teachers [44].

Lack of these, according to Abdulahi [1] and Ogbeba [36], had reduced classroom instruction to mere descriptive exercises through the use of the traditional teaching approaches with little or no student-centred learning. Perhaps, that is why Ayodele [8] suggested that the use of inappropriate non-effective teaching strategies is a major factor hindering students' understanding and achievement in mathematics. For example, Ayodele [8] and Bature and Jibrin [13] asserted that effective teaching of mathematics do not require theoretical and lecture teaching approaches or the applications of the teacher-chalk teaching approaches that had dominated most Nigerian mathematics classrooms. Rather, they asserted that effective mathematics teacher sometimes need to analyses the effectiveness of their classroom instruction in relation to students' academic and social needs and make effort to ensure that they aligned their classroom instruction in the way that will assist students to achieve these academics and social needs.

Similarly, the connection between effective instruction and positive student social behaviour during mathematics classroom instruction is an important ingredient, which according to Scott, Nelson, and Liaupsin, [39] is a well-established phenomenon in literature. One of these positive students social behaviour is the driving force in this 
paper, which is the concept of inclusivity as a tool for achieving quality mathematics classroom instruction. Therefore, the aim of this study is to investigate the effectiveness of using inclusivity as a tool for achieving quality mathematics classroom instruction in Nigerian Mathematics classroom. Three research questions guided the study and these include:

1. What were the perceptions of the students on the initial implementation of inclusive classrooms created by the preservice Mathematics teachers?

2. What inclusive classroom strategies were employed by the preservice Mathematics teachers during their classroom instruction as perceived by the focus group students?

3. What are the benefits of these strategies on student's participation and engagement in classroom instruction?

Inclusion is generally an acceptable services and instruction provided by a mathematics teacher to students with diverse background [29, 31 \& 41]. These services provided must be appropriate to the general instructions in the classroom. According to Ajunwon, [4] inclusiveness is a process of enhancing the capacity of classroom instruction to reach out to students with diverse abilities and background. The basis of these inclusions is to help students with special needs have the right to benefits from whatever activities going on in the classroom. This inclusive mathematics classroom instruction is that mathematics classroom where all students, regardless of strength or weakness, ability or disability, gender or socioeconomic background are given equal access to mathematics content and its pedagogies during mathematics classroom instruction [7, \& 14]. Barker, Frederiks and Farrely [10] were of the view that an inclusive mathematics classroom is that classroom where both students and their mathematics alike recognize, appreciate and capitalize on the difference and diversities found in the class to enrich the overall learning experiences of students during classroom instruction. This could be achieved through providing the students with the needed modifications and supports alongside their peers during classroom instruction [4].

While inclusive classroom teaching strategies could be view as any mathematics classroom teaching approaches that addresses the needs of students from varied backgrounds, learning styles, and abilities [6]. It is also pertinent to note here that sometimes, inclusive classroom teaching strategies could influence mathematics teachers to work with the whole class, small groups, and/or taking individual students on one-on-one with them. However Ajunwon [3] suggested that children with learning disabilities can only be removed from the regular classroom environment when the nature or severity of their disability is such that education in regular classes even with the use of supplementary services cannot be accomplished. Baseline levels of students also sometimes influence or inform mathematics teachers' decision while adopting inclusive classroom teaching strategies particularly students with special needs [6] this can inform the decision of the mathematics teacher whether his/her students need direct or individual skill instruction, practice, and remediation and/or enrichment programs [7\&14]. Inclusive mathematics classroom instruction at its best moments involves both general and special education mathematics teachers forming collaborative respectful partnerships that honor all students with diverse need and from different levels [7].

These strategies contribute to an overall inclusive learning environment, in which students feel equally valued irrespective or abilities or disabilities. Therefore, it is important that the pedagogical strategies we employ in the classroom during mathematics classroom instruction should reflect an understanding of the different students' identities that exist in the mathematics classroom so that we can anticipate the tensions that might occur in the classroom and be proactive about them [6]. Therefore, fostering inclusivity during mathematics classroom will encourage students irrespective of their age, gender, ethnicity, religious affiliation, socioeconomic status, sexual orientation or political beliefs with the aims of developing students' social and academic skills $[9,16, \& 23]$. Similarly, this suggest that providing equal opportunity with some motivation and attention to all students irrespective of ability, gender or socioeconomic status during classroom instruction can also help improved students participation and engagement in mathematics and mathematics-related subjects [22 \& 30].

Considering the importance of increasing inclusivity during mathematics classroom instruction, Greer [25] suggested two overarching issues that could help promote and increase inclusivity particularly to mathematics classroom instruction. The first issue is that of fostering the feelings of student belongingness during mathematics classroom instruction. Literatures has it that in most mathematics classrooms, students enter what they perceived to be an unwelcoming or even hostile and unfriendly mathematics classroom [17 \& 28] particularly, in Nigeria and in other countries where teacher-centred traditional classroom instruction dominates mathematics classroom activities which cannot fostered effective inclusivity. Therefore to assist students overcome these challenges mathematics teachers need to create a sense of belonging among students during classroom instruction.

Therefore, in increasing a sense of belonging among students during mathematics classroom instruction, Locks, Hurtado, Bowman, \& Oseguera, [32. p279] suggested that mathematics teachers have the role of building relationships among students and developing multicultural skills that will forester this relationship during mathematics classroom instruction, particularly in diverse multicultural backgrounds of Nigerian mathematics classrooms. Mathematics teachers, according to Hurtado, [27] must also ensure that students of underrepresented populations have the needed support to be academically successful during mathematics classroom instruction. The mathematics teacher most also work hard by enhancing students' ability to participate in a pluralistic, and interdependent classroom activities which in turn will 
increase the level of students engagement and participation in mathematics classroom activities [11].

Studies on inclusivity had repeatedly showed that positive and diverse interactions between students and their teachers and among students' increases when teachers identify, recognize and provide sense of belonging to students during mathematics classroom instruction [11 \& 32]. Greer [25] in his own study suggested that the identification of student cultures and the fostering of positive diversity and experiences among students during mathematics classroom instruction will helped students during classroom instruction to feel valued and part of the classroom community, while the interactions that result in feelings of social anxiety and fear during classroom instructions can decrease students sense of belonging and engagement during mathematics classroom instruction [11].

The second issue of inclusivity raised by Greer [25] which could be discussed in relation to mathematics classroom instruction is the stereotype threat mathematics teachers particularly in Nigerian demonstrate during classroom instruction. This could be refers to as the fear of confirming a negative stereotype behaviour exhibited by the teacher or the dominant group during mathematics classroom instruction [34 \& 35]. This type of fear can create high cognitive load and reduce academic focus and performance [43] among students. The effects of these stereotype threats to students during mathematics classroom instruction particularly in the Nigerian mathematics classrooms had impacted negatively too many students, particularly students from a less dominant group or from low socio-economic backgrounds [34 \& 35].

Several studies in literature had suggested that stereotype threat significantly reduces performance of students particularly among the undergraduates' students of less privileged socioeconomic group [18, 42, \& 43]. Similarly, female senior secondary schools students who tend to exhibit some level of appreciable performance academically in mathematics and science tend to suffer the same fate in most Nigerian mathematics classroom [11, 12 \& 24]. Stereotype threat is especially detrimental to students who identify strongly with the stigmatized group as suggested by Marx, Stapel, \& Muller, [33]. To increase inclusivity during mathematics classroom instruction therefore, mathematics teachers must make concerted effort in identifying and eliminating stereotype threat during their classroom instructions. Such mathematics teachers should also make it a central goal to increasing inclusivity during their mathematics classroom instruction.

Developing effective inclusivity and fostering diversity during Mathematics classroom instructions among students is a very important factor to achieving quality mathematics classroom practice. Greer [25] was of the view that, encouraging effective classroom discussion among students, is believed to be one of the effective strategies for fostering diversity among students, especially by introducing medium-sized mathematics classroom which could be viewed as grouping of students into small groups. Similarly, developing inclusive mathematics classroom instructions as a tool for influencing students' attitudes, feelings and behaviour could easily be achieved through the recognition of diversities found in the mathematics classroom and thereby influence the achieving of quality classroom practice.

\section{Materials and Methods}

This research adopts a qualitative collaborative case study of four preservice teachers through a community of practice approach to seek data for this study. The collaborative approach in this research is the form of collaborative research where two or more people are involved in working together either through natural and social settings with the view to improve their practice. Working together through a community of practice help teachers take holistic approach in tackling classroom challenges and or problems that one teacher can hardly confront working alone.

Four Preservice Mathematics teachers taught mathematics in four classes in three secondary schools in Bauchi, Plateau and Kaduna states of Nigeria for a period of fifteen weeks. The researcher observed each of the preservice teachers for a period of ten weeks between October and December 2011 and again for five weeks between February and March 2013.

Six senior secondary two students (Pseudonyms: Jane, Janet and Julie girls and Mike, Michael and Mark boys) were purposively selected for a focus group discussion with the researcher on the classroom teaching of the four teachers which constituted the major data for this study. In the second phase of the research, the researcher interacted also with six senior secondary one students (pseudonyms: Jenifer, Juliet, Jasmin, girls and Jerome, Bosam, and James) for the purpose of collecting their own views on the inclusive classroom created. The students were also purposively selected for an interaction with the researcher. The researcher also interacted with each of the teachers throughout the observations period. Classroom instructions were videotaped. Data analyzed in this paper concentrated on the views of the six focus group students about the inclusive classroom settings created by the preservice teachers in the first phase of the research. However, few reference s were made on the second phase of the research. The grounded theory approach was adopted to analyze the data collected.

\section{Results}

Three research questions were postulated to guide this study. First, the researcher discussed the initial practice of the preservice teachers using inclusive classrooms instruction. Second, the researcher discussed the strategies adopted by the preservice teachers to implement inclusive classroom instruction during their classroom practice. And finally, the researcher discussed the benefits of introducing inclusive classrooms in the Nigerian mathematics classrooms. 


\section{Response to Research Question 1}

What were the perceptions of the students on the initial implementation of inclusive classrooms created by the preservice mathematics teachers?

Data collected suggested that students' initial views of the preservice mathematics teachers' classrooms were that of fear, anxiety and timidity. This is because of the unfriendly approach to classroom instruction adopted by the preservice mathematics teachers that were used in this study. One of the student during the focus group discussion asserted that most of the preservice mathematics teachers during the classroom instruction concentrated on their usual traditional classroom practice with no provision for students' inclusion.

"Before..., the mathematics teacher will just come and be talking..., talking..., talking..., you sometimes find it difficult to understand what he is saying and you dare not talk." (Janet)

In support of the view of Janet, Mike commented that;

"Sometimes, the way the teachers address students makes them dislike mathematics and indeed the mathematics teacher... I mean the teachers approach to the student is not friendly." (Mike)

From the view of the students above it is pertinent to note that the attitude of teachers to teaching and to the students affects students' inclusion during mathematics classroom instruction. In view of this, mike was of the view that this leads to students' exclusion and further leads to disengagement during classroom instruction. The focus group students were further of the view that some of these young adult feels humiliated during classroom practice.

Some students' sometimes feel humiliated and sometimes say the mathematics teacher is wicked. He is not friendly, and hence they will not like his teaching no matter how good the teacher is. (Mike)

However, as the research progresses, students' views of the new classroom setting created by the teachers improved. This suggests that if mathematics teachers create classrooms that are inclusive, students participating in such classroom instruction will improve. Janet supported this assertion when commenting on the classrooms environment created by one of the preservice teachers.

The concept of inclusion ... makes all students equal..., teachers were not harsh and hard on students... there was cordial relationship between teachers and students and everybody was regarded and respected..., a mathematics teacher that is friendly listened to every student, and every student contributes to his classroom teaching and had his/her opinion counts. (Janet)

Similarly Julie added by saying that,

The teachers were friendly..., carry everybody in the class along..., recognize the different kind of people in the class..., nobody feels inferior or superior..., boys and girls were recognized and respected. (Julie)

\section{Response to Research Question 2}

What inclusive classroom strategies were employed by the preservice Mathematics teachers during their classroom instruction as perceived by the focus group students?

Data collected suggested that the preservice teachers made students sit in groups as against the traditional congregational classroom seating that prevails in Nigerian mathematics classrooms. This suggested the first strategy the preservice teachers adapted to achieve inclusivity during their classroom instruction. Jane was first to identify this and said,

"We were fixed to sit in groups like in a circular form, and we were made to interact with one another in the class, that encourages the slow learners and they were not left out they were carried along." (Jane)

Another inclusive strategy adopted by the preservice teachers during their classroom instruction according to focus group discussion students was the introduction of the collaboration to problem solving. Even though this was initially resisted by the students in the first class as claimed by one of the students...

"This was very strange..., I thought we have been taught that when problems are given in the class we should cover our work or we should not allow anybody to see what we are doing..., but asking us to work together looks strange..., sincerely to tell you the truth I initially felt this is morally wrong..., as if these teachers did not know that this is a mission school..., but our teachers were with them and supported it..., it was strange..., but as we progressed I discovered I learnt more from my colleagues especially as you know mathematics is a very difficult subject..., (laugh...,)" (Juliet)

From Julie's comment above, it shows that as the preservice teachers progressed, the students tend to have a change of attitude to the new classroom instruction created by the preservice teachers. According to the focus group students, the teachers made sure students collaborated during their classroom instruction. Students were made to share their ideas and understandings with their colleagues thereby creating opportunities for assisting one another particularly students with learning challenges. For example Mike was of the view that:

"I might have no idea at all but mixing up with other students I means my classmates makes it easier..., when I have the idea of step one..., another students have the idea of step two... step three..., when we put the ideas together it helps us get the solution faster..... You also learnt faster than when you are working alone depending only on the teacher." (Jenifer)

Another student also said;

"To me, I like this type of approach..., because before I preferred working on my own..., this is because I 
sometimes want to contribute something but I feel that what I will say will not be correct and others might laugh at me..., but the teacher made us feel that what we felt were mistakes or wrong might end up being the idea the class is looking for to move forward. (Jane)

Similarly, there were gender inclusions to ensure classroom responsibilities were not restricted to the domineering male students, the girls were recognized and encouraged to contribute meaningfully to the classroom instruction. This contradicted the general views of teachers and researchers in Nigerian mathematics classrooms that girls perform below expectation when it comes to mathematics. The data from the study suggested that if girls are given equal opportunities to participate in classroom activities during classroom instruction as boys, they can perform even better. Janet supported this assertion by saying,

"The mathematics teachers recognize the presence of females' students during their classroom teaching..., not that the males students were neglected..., but because the teachers recognized that we females' students sometimes feels mathematics is for boys and not girls". (Janet)

Finally, the teachers also adopted a student-centred learning approach to their classroom instruction. The students were of the view that they were made to take responsibility for their learning. This provided opportunities for the students to direct their learning with teachers working as mere participants in the classroom. It also provided opportunities for students to assist one another on areas they discovered difficult particularly students with learning challenges. Jane observed that:

"The seating positions created by the mathematics teachers tend to encourage slow learners. We were fixed to sit in groups like in a circular form, and we were made to interact with one another in the class, that encouraged the slow learners and they were not left out..., they were carried along. It also made us so engaged; we debated and defended our solutions... and everybody was contributing his or her ideas in the class." (Jane)

\section{Response to Research Question 3}

What are the benefits of these strategies on student's participation and engagement in Mathematics classroom instruction?

Data collected from the focus group students revealed benefits associated with inclusive classrooms were identified by the students. Some of these benefits were includes; Inclusive classrooms encourages slow learners and makes learning all-inclusive. This suggests that when mathematics teachers create classroom that are inclusive slow learners are helped and assisted during the classroom instruction.

"The sitting posture created by the mathematics teachers' tends to encourage slow learners. We were fixed to sit in groups like in a circular form, and we were made to interact with one another in the class, that encourage the slow learners and they were not left out..., they were carried along. It also made us so engaged." (Jane).

Julie supported Jane by saying;

"The dormant group were fully recognized and carried along. Every student's opinion was respected...; the teacher made sure everybody was carried along and was be able to solve problems, which means she wanted everybody to be involved." (Julie)

Similarly, when teachers created classroom environment that are inclusive, classroom barriers especially teacher/students and student/student relationship improve. This created a room where students' views were respected according to Julie who asserted that "every student's opinion was respected...; (Julie)" while Jane was of the view that inclusive classrooms encourage cooperation among students where useful and meaningful ideas are shared and learnt between students;

"Inclusion makes us identify some good things others know that we do not know.... I discovered we all worked with passion and make everybody involved.... whatever idea you have you simply say it and nobody said anything against it but rather your simple ideas is digested and help leads to the solution." (Jane)

In supporting the view of Jane, Mark asserted that if an inclusive classroom students are brought together to see mathematics problems given to them as a general problem, that can best be solved collaboratively.

"The approach brings all students together to see mathematics as a common problem not as an individual problem. The approach was very interesting, we sit in groups to solve the problems together, and we worked on our own, without the unnecessary interference from our teacher." (Mark).

In supporting the view of Mark, Julie, commented on the inclusive classroom created by their teachers and was of the view that,

"This is not only you alone thinking on how to solve a particular problem, the thinking is in a group, by the time we join our heads together and think on a solution to a particular mathematics problem, you bring your idea... I bring my idea..., the solution becomes easier. " (Julie)

Thirdly, the focus group students were of the view that Inclusive classroom encourage gender inclusion. This implies that effective mathematics classrooms are those that make equal learning opportunities for both males and females students during classroom instructions. Janet supported this assertion by saying that;

"The teacher was in the kind of encouraged the girls in 
the class, that they can also do well in mathematics and even better than the domineering boys. It is generally believed that boys are usually regarded as the mathematics Gurus because everybody believed that girls are always left behind in mathematics. But the teachers made us to understand that it is not true, we female students can do it also and even better, so the girls were encouraged by their encouragement." (Janet)

Janet went further to buttressed her view by saying,

"Seeing a female teacher teaching mathematics also made a world of difference and encouragement in the part of the girls in the class." (Janet)

Finally, data collected in this research suggested that inclusive classrooms provide opportunity for students to help one another. This suggests that when mathematics teachers create classrooms that are inclusive, students are supported to learn from their colleagues and not necessarily from their teachers. While commenting on the beauty of inclusivity and its attendant benefit to classroom instruction Jane asserted that,

"It's like someone is always there... very close to you... to say, O Girl? Is there any problem? Do it this way, this way, and this way... the classmates also... the teacher... is always there... willing to assist... willing to show the way." (Jane)

Similarly, Janet made a similar view with that of Jane, however, added that beautiful lessons are learnt from one another when mathematics teachers create classrooms that are inclusive.

"Inclusion makes us identify some good things others know that we don't know... I discovered we all worked with passion and make everybody involved..., whatever idea you have you simply say it and nobody said anything against it but rather your simple ideas is digested and help leads to the solution." (Janet)

\section{Discussions}

The findings of this study suggest that the preservice teachers started their classroom instruction with the usual traditional classroom instruction they were conversant with. Some of the issues identified by the focus group students as traditional in the initial classroom instruction of the preservice teachers were the general stereotype threat in the traditional Nigerian teacher-student relationship which according Bature and Bature [12] and Marx, Stapel, and Muller, [33] is detrimental to students' inclusion and engagement during classroom instruction. The effect of this poor teacher-student relationship was identified by Murdock \& Hoque, [34] and Murdock \& Swanson, [35] as having negative impact on students' social behaviour particularly students from the low socio-economic group which was also observed by the focus group students in the study which according Steel and Aronso [43] sometimes create high cognitive load and thereby reduce students' performances.

However, there were elements of improvement in the classroom instruction of the preservice teachers as the research progresses. Similarly from the response of the students in research question two, the study suggested that some strategies were adopted by the preservice teachers to encourage effective inclusion. Some of the strategies identified include grouping students into smaller strata, encouraging collaboration among students, and adopting gender inclusion by involving both boys and girls in the classroom activities. This supports the findings of Bature, [11]; Greer [25] and Locks et al, [32] who were of the view that inclusivity had repeatedly showed that positive and diverse interactions between students and their teachers and between students increases when teachers identify, recognize and provide sense of belonging to students during mathematics classroom instruction, while Ajunwo [4] believed that effective classroom inclusion can likely translate into instructional approaches that will better meet the needs of the heterogeneous classroom groupings.

The result of the study suggests that providing equal opportunity with some motivation and attention to all students irrespective of ability, gender or socioeconomic status during classroom instruction will help improved students participation in mathematics and mathematics related subjects, [22 \& 30]. For example in Nigerian classrooms, girls generally feels mathematics is male-gender related; while females are better-off in areas involving linguistic and arts related professions, similarly in their view Fennema and Sherman [19 \& 20] believed that the usefulness of, and confidence exhibited in learning mathematics, among males students provide more evidence that they are more confident about mathematics and therefore believed that mathematics was, and would be, more useful to males than females students. However, the findings of the study, suggested that there is no sharp contradiction on the believed of Fennema and Sherman [19 \& 20] and the findings of the study on Gender. It was observed from the study that if girls are given equal opportunity to strive in their studies as their male counterparts, they could also be observed to be better mathematics students.

In view of the above, it suffices to suggest that providing classrooms that are inclusive for every student in the class irrespective of gender, ability, or socioeconomic status during mathematics classroom instruction is very important and relevant in the light of recurring questions about how to capture students interested and involvement in mathematics and mathematics related disciplines [2, $6 \& 21]$. This can only be achieved if mathematics teachers adopt strategies and techniques that will foster effective integration and inclusion during mathematics classroom instruction $[15 \&$ 37] in which some of these strategies were identified in this study. Findings from previous researches also suggested that, the ultimate goal of inclusion is to create classrooms were mathematics teachers are prepared to recognize all students and create opportunities for all students to participate equally in all aspects of mathematics classroom learning [40 \& 45]. 


\section{Conclusions}

It is therefore recommended that teachers of mathematics as administrators of classroom instructions should endeavor to understand the educational techniques that will improve students' interest and engagement in mathematics classroom teaching, which, the adoption of inclusivity during mathematics classroom is highly recommended. This is because; if mathematics teachers take positive measures to provide classrooms that are inclusive and participatory to all students irrespective of ability, gender or socioeconomic status positive engagement in mathematics will be achieved. It is also very important for mathematics teachers to note that the proponents of the policy on inclusive education are now reaffirming their commitment to education for all [4]. Therefore in acknowledging the urgency of providing mathematics classrooms for the marginalized students during classroom instruction, teachers of mathematics should take into account the socio-cultural identities present in their classrooms profitably during their classroom instruction. Finally, as earlier stated in this paper, mathematics teachers should make effort to develop socio-cultural identities that can anticipate challenges that might occur during their classroom instruction and take proactive steps to combat such challenges before they affect the effectiveness of students' engagement and participation during mathematics classroom instruction [5].

\section{REFERENCES}

[1] Abdulahi, A. Functional Science, Technology and Mathematics Education for National Economic Empowerment and Development. A Speech Delivered at the 2007 School of Science National Conference held at Federal College of Education, Zaria, and April 2 - 5 [2007]

[2] Ahmed, S., \& Bora, A. Gender differences and achievements in mathematics among the students in high school examination in Diphu Town of Karbi Anglong District of Assam, India. International Journal of Mathematical Education, 2011, 1(1), 57-62.

[3] Ajuwon, P. M. Inclusive Education for Students with Disabilities in Nigeria: Benefits, Challenges and Policy Implications. International Journal of Special Education, 2008; 11-17.

[4] Ajuwon, P. M. Trainees' Perceptions of Inclusive Education in Nigeria: A Preliminary Report. Ajobiewe T., Adebiyi, B. A., \& Nkangwung, F. O. (Eds.): Contemporary Issues in the Education of Persons with Visual Impairment. Ibadan, Nigeria: Glory-Land Publishing Co. 2011, 6-24.

[5] Ambrose, S. A., Bridges, M. W., DiPietro, M. \& Lovett, M. C. How learning works: Seven research-based principles for smart teaching. San Francisco, CA: Jossey Bass, 2010.

[6] Atnafu, M. Gender differences in mathematics attitude and achievement of tenth grade students' of Addis Ababa secondary schools. International Journal of Mathematical Education, 2011, 1(1), $35-48$.
[7] Atweh, B. The social turn in understanding learning and its implications for facilitating learning: ripples for change. A journey of preservice teacher education reforms in the Philippines Commission for Higher Education. Print house, Quezon City 2007.

[8] Ayodele O. O. Building A Sustainable Science Curriculum in Nigeria; Accommodating Local Adaptation, Leveraging Technology and Enhancing Ares of Improvement for Quality Assurance. Journal of Science Teachers Association of Nigeria 2006, 1(7)

[9] Banks, J. A. Multiethnic Education: Theory and Practice. Needham Heights, MA: Allyn \& Bacon. 1994.

[10] Barker, M., Frederik, E \& Farrelly B Creating a Culturally Inclusive Classroom Environment. GIHE Good Practice Resource Booklet Designing Culturally Inclusive Learning and Teaching Environments - Classroom Strategies. ttps:/www.griffith.edu.au/_data/assets/pdf_file/0011/18485 3/Creating-a-Culturally-Inclusive-Classroom-Environmentmcb2.pdf, 2013.

[11] Bature, I. J. Productive pedagogies for reforming secondary school mathematics classroom practice in Nigeria. Ph.D. thesis of Curtin University, Science and Mathematics Education Centre;

http://espace.library.curtin.edu.au/R?func $=$ dbin-jump-full\&l ocal_base=gen01-era02\&object_id=199968 2014.

[12] Bature, I. J., \& Bature, F. S. Effect of maths-phobia on students' attitude towards mathematics. Journal of Educational Studies, Institute Of Education, University of Jos, 2006, 12 (1), 6-12.

[13] Bature, I.J. \& Jibrin, A.G. The perception of preservice mathematics teachers on the role of scaffolding in achieving quality mathematics classroom instruction. International Journal of Education in Mathematics, Science and Technology, 2015, 3(4), 275-287.

[14] Bature, I. J. \& Atweh, B. Inclusivity: An effective tool for mathematics classroom practice in Nigerian secondary schools; Proceedings of the Australian Conference on Science and Mathematics Education, Australian National University ,http://openjournals.library.usyd.edu.au/index.php /IISME/article/view/6939/7496 2013.

[15] Boggiano, A. K. \& Pittman, T. S. Achievement and motivation: A social development perspective. Cambridge: Cambridge University Press.1992.

[16] Bromley, K. D. (1998). Language art: Exploring connections. Needham Heights, MA: Allyn \& Bacon

[17] Carter, D. F., Locks, A. M., Winkle-Wagner, R., \& Pineda, D "From when and where I enter": Theoretical and empirical considerations of minority students' transition to college. Paper presented at American Educational Research Association annual meeting, San Francisco. 2006, April.

[18] Croizet, J. C., \& Claire, T. Extending the concept of stereotype threat to social class: The intellectual underperformance of students from low socioeconomic backgrounds. Personality and Social Psychology Bulletin, 1998. 24, 588-594.

[19] Fennema, E., \& Sherman, J. Sex-related differences in mathematics achievement, spatial visualization, and affective factors. American Educational Research Journal, 1977, 14(1):51-71. 
[20] Fennema, E., \& Sherman, J. Sex related differences in mathematics achievement and related factors: A further study. Journal for Research in Mathematics Education, 1978, 9:189-203.

[21] Forgasz, H., \& Rivera, F. (Eds.). Towards Equity in Mathematics Education: Gender, Culture and Diversity, Advances in Mathematics Education. Heidelberg: Springer, 2012.

[22] Gage, N.L., \& Berliner, D.C. Educational psychology (5th Ed.). New Jersey: Houghton Mifflin Company. 1992

[23] Garcia, E. Understanding and meeting the challenge of student cultural diversity; Boston: Houghton Mifflin, 1994

[24] Good, C., Aronson, J., \& Harder, J. Problems in the pipeline. Journal of Applied Developmental Psychology, 2008, 29, 17-28.

[25] Greer Classroom Management Strategies for Inclusive Classrooms, Published Online June 2015 In Sci-Res. http://www.scirp.org/journal/ce http://dx.doi.org/10.4236/ce.2015.610094

[26] Hiebert, J., Gallimore, R., \& Stigler, J. W. A knowledge base for the teaching profession. Educational Researcher, 2002, $31(5), 3-15$.

[27] Hurtado, S. Preparing College Students for a Diverse Democracy: Final Report to the U.S. Department of Education, OERI, and Field Initiated Studies Program. Ann Arbor, MI: Center for the Study of Higher and Postsecondary Education. 2003.

[28] Kalsner, L., \& Pistole, M. C. College adjustment in a multiethnic sample: Attachment, separation-individuation, and ethnic identity. Journal of College Student Development, 2003, 44(1), 92-109.

[29] Kleinfeld, J. No map to manhood: Male and female mindsets behind the college gender gap. Gender Issues, 2009, 26(3-4), 171-182.

[30] Lepper, M. R. Motivational considerations in the study of instruction. Cognition and Instruction, 1988, 5, 289-309.

[31] Lindsay, G. Inclusive education: a critical perspective, British Journal of Special Education, 2003, 30(1), 3-11.

[32] Locks, A.M., Hurtado, S., Bowman, N.A., \& Oseguera, L. (2008). Extending notions of campus climate and diversity to students' transition to college. Review of Higher Education, $31,257-285$.

[33] Marx, D.M., Stapel D.A, \& Muller, D. We can do it: The interplay of construal orientation and social comparisons under threat. Journal of Personality and Social Psychology. $2005,88,432-446$

[34] Murdock, S. H., \& Hoque, N. Demographic factors affecting higher education in the United States in the twenty-first century. New Directions for Higher Education, 1999 (108), $5-13$.

[35] Murdock, S. H., \& Swanson, D. Applied demography in the 21st century: Selected papers from the Biennial Conference on Applied Demography, San Antonio, Texas, January 7-9, 2007 (Applied Demography Series, Vol. 1). Amsterdam, the Netherlands: Springer.

[36] Ogbeba J.A. Using advance organizers to improve the teaching and learning of Biology: A case for specific objectives. Journal of Educational Innovators, 2010, 3 (2), $184-190$

[37] Okojie, C. E. Female Under-Schooling in Africa as Assessed by the African Academy of Sciences Research Programme. Paper presented at the International Colloquium - Gender, Population and Development in Africa, Abidjan, Nigeria, 16 21 July 2001.

[38] Purdie, N., \& Ellis, L. A review of the empirical evidence identifying effective interventions and teaching practices for students with learning difficulties in Years 4, 5 and 6. A report prepared for the Australian Government Department of Education, Science and Training. Camberwell, VIC: Australian Council for Educational Research, 2005. Available for download in PDF format at: http://www.acer.edu.au/research/programs/documents/literat urereview.pdf

[39] Scott, T.M., Nelson, C.M., \& Liaupsin, C.J. Effective instruction: The forgotten component in preventing school violence. Education and Treatment of Children, 2001, 24, 309-322

[40] Shadreck, M. Bachelor of education in service teacher trainees' perceptions and attitudes on inclusive education in Zimbabwe. Asian Social Science, 2012, 8(13), 227- 232. S

[41] Snyder, T. D., \& Dillow, S. A. Digest of education statistics 2009 (NCES 2010-2013). Washington, DC: U.S. Department of Education, Institute of Education Sciences, National Centre for Education Statistics. 2010.

[42] Spencer, B., \& Castano, E. Social class is dead. Long live social class! Stereotype threat among low socioeconomic status individuals. Social Justice Research, 2007, 20, 418 432 .

[43] Steele, C. M., \& Aronson, J. Stereotype threat and the intellectual test performance of African Americans. Journal of Personality and Social Psychology, 1995, 69(5), 797-811.

[44] Stigler, J. W., \& Hiebert, J. Improving Mathematics Teaching; Improving Achievement in Math and Science, 2004, 61(5), pp 12-17

[45] Swain, K. D., Nordness, P. D., \& Leader-Janssen, E. M. Changes in Preservice Teacher Attitudes toward Inclusion, Preventing School Failure. Alternative Education for Children and Youth, 2012, 56(2), 75-81.

[46] Westwood, P.S. Constructivist approaches to mathematical learning: A note of caution. In D. Barwood, D. Greaves, and P. Jeffrey. Teaching numeracy and literacy: Interventions and strategies, 1999.

[47] Westwood, P.S. Teaching and learning difficulties: Cross-curricular perspectives. Camberwell, VIC: Australian Council for Educational Research, 2006 